Review

\title{
Recent Development of Nano-Materials Used in DNA Biosensors
}

Kai Xu ${ }^{1,2}$, Junran Huang ${ }^{1}$, Zunzhong Ye ${ }^{1}$, Yibin Ying ${ }^{1, *}$ and Yanbin $\mathrm{Li}^{3}$

${ }^{1}$ School of Biosystems Engineering and Food Science, Zhejiang University, Hangzhou, Zhejiang Province, China, 310029; E-Mails: xk021402173@yahoo.com.cn (K.X.); hjr8400@yahoo.com.cn (J.H.); zzye@zju.edu.cn (Z.Y.)

${ }^{2}$ Qingdao Institute of Bioenergy and Bioprocess Technology, Chinese Academy of Sciences; Key Laboratory of Biofuels, Chinese Academy of Sciences, Qingdao, Shandong Province, 266101, China

${ }^{3}$ Department of Biological \& Agricultural Engineering, University of Arkansas, Fayetteville, AR 72701, USA; E-Mail: yanbinli@uark.edu

* Author to whom correspondence should be addressed; E-Mail: yingyb@zju.edu.cn; Tel.: +86-571-869 718 85; Fax: +86-571-869 71885

Received: 3 June 2009; in revised form: 6 July 2009 / Accepted: 8 July 2009 /

Published: 14 July 2009

\begin{abstract}
As knowledge of the structure and function of nucleic acid molecules has increased, sequence-specific DNA detection has gained increased importance. DNA biosensors based on nucleic acid hybridization have been actively developed because of their specificity, speed, portability, and low cost. Recently, there has been considerable interest in using nano-materials for DNA biosensors. Because of their high surface-tovolume ratios and excellent biological compatibilities, nano-materials could be used to increase the amount of DNA immobilization; moreover, DNA bound to nano-materials can maintain its biological activity. Alternatively, signal amplification by labeling a targeted analyte with nano-materials has also been reported for DNA biosensors in many papers. This review summarizes the applications of various nano-materials for DNA biosensors during past five years. We found that nano-materials of small sizes were advantageous as substrates for DNA attachment or as labels for signal amplification; and use of two or more types of nano-materials in the biosensors could improve their overall quality and to overcome the deficiencies of the individual nano-components. Most current DNA biosensors require the use of polymerase chain reaction (PCR) in their protocols. However, further development of nano-materials with smaller size and/or with improved biological and chemical properties would substantially enhance the accuracy, selectivity and
\end{abstract}


sensitivity of DNA biosensors. Thus, DNA biosensors without PCR amplification may become a reality in the foreseeable future.

Keywords: nano-material; DNA biosensor; substrates; signal amplification

\section{Introduction}

With the increased understanding of the structure, organization, sequence and function of nucleic acid molecules, sequence-specific DNA detection has become increasingly important. Detection of specific DNA sequences is needed in many fields: the Human Genome Project is providing massive amounts of genetic information that should revolutionize our understanding and diagnosis of inherited diseases [1]; pathogens responsible for human and animal diseases, bacteria and viruses, are detectable via their unique nucleic acid sequences [2-5]; genetically modified organisms (GMOs) could also be detected via their specific nucleic acid fragments of artificial introduction [6,7]. It also holds enormous potential for the development of new and specific therapeutic procedures, new drug research and development, gene therapy, food technology, environmental sciences, etc [8-12]. Therefore, development of a simple, rapid and user-friendly method for specific DNA sequences testing has become increasingly important to meet these needs.

Conventional methods for the analysis of specific gene sequences are carried out using gel electrophoresis of DNA fragments amplified by the polymerase chain reaction (PCR) using primers that are sequence-specific for the chosen region of DNA. Although it is simple and effective for the detection of PCR products, gel electrophoresis fails to provide any sequence information about the amplified DNA. Furthermore, the use of PCR is limited to laboratories because of its complexity in obtaining proper primers design and the corresponding empirical conditions for consistent amplification [13]. Southern blotting satisfies the requirement for sequence information, but it is not recommended for routine analysis, as it involves several steps [14].

In recent years, DNA biosensors based on nucleic acid hybridization have been vigorously pursued. DNA biosensors are defined as analytical devices incorporating a single-stranded oligonucleotide (probe) intimately associated with or integrated within a physicochemical transducer or transducing microsystem, which may be optical, electrochemical, thermometric, piezoelectric, magnetic or micromechanical. The aim of a DNA biosensor usually is to produce either discrete or continuous measurable signals, which are proportional to the concentration of complementary (target) DNA sequence. Because of their specificity, speed, portability, and low cost, DNA biosensors offer exciting opportunities for sequence-specific DNA detection. However, the concentration of genetic targets is very low in biological samples, making it unsuitable for detection by a DNA biosensor. Therefore, an ultrasensitive method of detecting nucleic acids is clearly essential.

In order to achieve high detection sensitivity, researchers have developed many techniques to enhance the response of DNA biosensors by modifying the sensors with different functional materials. Within the growing and increasingly complex area of nanotechnology, great attention has been paid in recent years to nano-structured materials of different chemical composition, produced as nanoparticles, nanowires or nanotubes. Nano-materials are larger than individual atoms and molecules but are smaller 
than bulk solids, therefore they obey neither absolute quantum chemistry nor the laws of classical physics and have properties that differ markedly from those expected. There are two major phenomena that are responsible for these differences. First is the high dispersity of nanocrystalline systems [15]. As the size of a crystal reduces, the number of atoms at the surface of the crystal compared to the number of atoms in the crystal itself, increases. The second is called size quantization and arises because the size of nano-materials is comparable to the de Broglie wavelength of its charge carriers [16]. Because of the spatial confinement of the charge carriers, the edge of the valance and conduction bands split into discrete, quantized, electronic levels. These electronic levels are similar to those in atoms and molecules. Because of these two unique phenomena which occur in nano-materials, their properties (electrical, optical, chemical, mechanical, magnetic, etc.) can be selectively controlled by engineering the size, morphology, and composition of the particles. These new substances will have enhanced or entirely different properties from their parent materials.

The nano-materials used in DNA biosensors including nanoparticles, like gold ( $\mathrm{Au}$ ) nanoparticles, Cadmium sulfide (CdS) nanoparticles; nanowires like silicon ( $\mathrm{Si}$ ) nanowires, nanotubes like carbon nanotubes, etc. There are mainly two purposes of using nano-materials in DNA biosensors: as substrates for DNA attachment and as signal amplifiers for hybridization. The aim of this article is to summarize the various nano-materials used in DNA biosensors based on the two purposes in recent years, including the information on applications and future prospects.

\section{Nano-Material as Substrates for DNA Attachment}

As we know, the most critical step while preparing a DNA biosensor is the immobilization of DNA probe on the surface of a sensing device such as an electrode. The amount of immobilized DNA probe will influence the accuracy, sensitivity, selectivity, and life of a DNA biosensor directly. Because of the high surface-to-volume ratio and excellent biological compatibility, nano-materials can enlarge the sensing surface area to increase the amount of immobilized DNA greatly, and the DNA mixed with nano-materials can keep its biological activity well.

\subsection{Nanoparticles}

Over the past decade, the unique properties of nanoparticles have continued to attract considerable research attention. Nanoparticles, especially metal nanoparticles, offer excellent prospects for chemical and biological sensing because of their unique optical, electrical, and thermal properties as well as catalytic properties [17-19]. The nanoparticles were prepared mainly through reduction reactions in aqueous solutions containing the corresponding chloro-metallate anions, metal vapor synthesis routes, electrochemical depositions on inert bases, sol-gel, or deposition-precipitation [20-24]. The surface and geometry of nanoparticles can be tailored to bind a subset of biomarkers selectively. Figure 1 shows the schematic representation of nanoparticles as substrates for DNA attachment. 
Figure 1. Schematic representation of nanoparticles as substrates for DNA attachment.

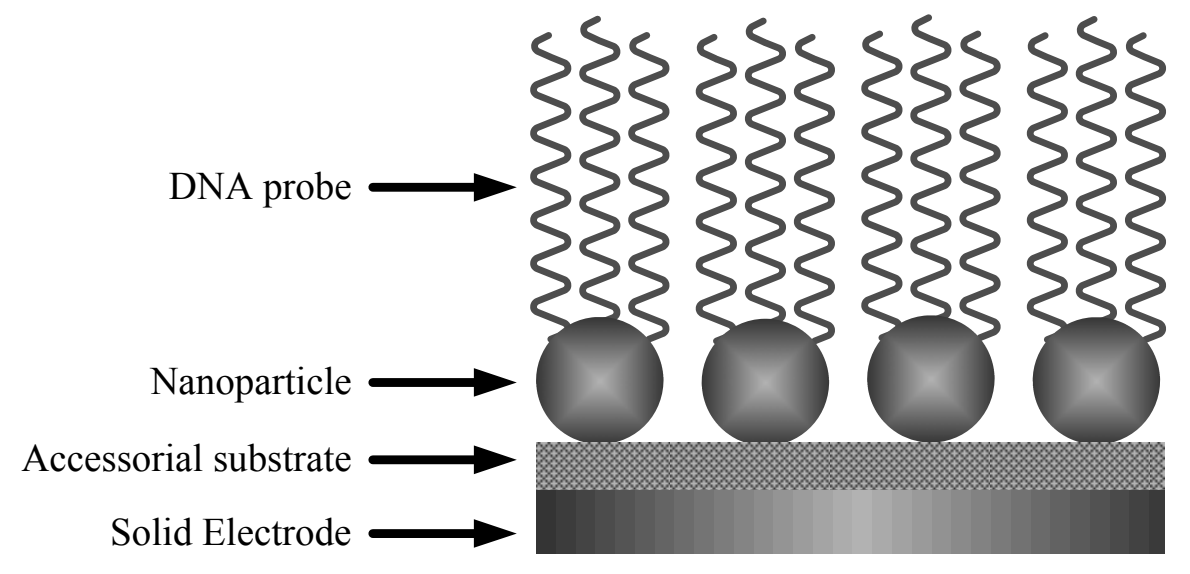

\subsubsection{Gold Nanoparticles}

Gold $(\mathrm{Au})$ nanoparticles are a hot study topic lately and they play a key role in DNA biosensors. Thiol-Au ( $\mathrm{SH}-\mathrm{Au})$ linkages usually were used to bind $\mathrm{Au}$ nanoparticles covalently with solid electrodes or DNA because of the strong affinity of covalent bonds between sulfur atoms and gold atoms. Jin et al. [25] immobilized the calf thymus DNA on the surface of Au nanoparticles which were co-immobilized at a gold electrode through 4,4'-bis(methanethiol)biphenyl (MTP) molecules by an assembly process. Their results indicated that the $\mathrm{Au}$ nanoparticles modified gold electrode can enlarge the electrode surface area and enhance the amount of immobilized single stranded DNA (ssDNA) greatly, and the surface coverage value of DNA molecules decreased as the size of the gold nanoparticles increased. Fu et al. [26] also fabricated an Au nanoparticles modified DNA biosensor though thiol-Au linkages. The thiol groups of 3-mercaptopropyltrimethoxysilane (MPTS) served as binding sites for the covalent attachment of MPTS to a gold electrode surface. After hydrolysation and condensation, the polymerized monolayer, one-dimensional network of MPTS (1dMPTS) was combined together into a two-dimensional sol-gel network (2dMPTS). The second silane layer (B2dMPTS) was formed by immersing the electrode back into the MPTS solution, and then the Au nanoparticles were chemisorbed onto the thiol groups of the second silane layer. Finally, the mercapto oligonucleotide was self-assembled onto the surface via the Au nanoparticles. The results indicated that oligonucleotide immobilized in this way exhibits a good sensitivity, selectivity, stability and a long-term maintenance of bioactivity. Many other researchers [27-33] have used different reagents containing thiol groups to improve the DNA attachment though Au nanoparticles.

$\mathrm{Au}$ nanoparticles as substrates for DNA attachment though other linkages were also reported in several publications. Spadavecchia et al. [34] deposited the Au nanoparticles directly onto the surface of silicon ( $\mathrm{Si}$ ) and sapphire $\left(\mathrm{Al}_{2} \mathrm{O}_{3}\right)$ substrates by a physical method to prepare a DNA biosensor. Pan [35] prepared a DNA biosensor by self-assembling horseradish peroxidase-linked single-stranded DNA (HRP-ssDNA) onto gold nanoparticles-modified composite membrane at a carbon paste electrode (CPE). Yang et al. [36] fabricated the Au nanoparticles by electropolymerizing 2,6-pyridinedicarboxylic acid (PDC) on the glassy carbon electrode (GCE), and then DNA probe was immobilized on the $\mathrm{Au}$ nanoparticles by the interaction of $\mathrm{Au}$ with DNA. Kim et al. [37] deposited $\mathrm{Au}$ 
nanoparticles onto a porous anodic alumina (PAA) layer chip surface to form a "caplike" layer on the top of the oxide nanostructures in an orderly fashion.

\subsubsection{Platinum Nanoparticles}

Platinum $(\mathrm{Pt})$ nanoparticles were also used as substrates to improve DNA immobilization due to their high catalytic activities. Zhu et al. [38] fabricated an electrochemical DNA biosensor using Pt nanoparticles combined with multi-walled carbon nanotubes. Multi-walled carbon nanotubes and platinum nanoparticles were dispersed in Nafion, and then they were used to modify a glassy carbon electrode (GCE) surface. Oligonucleotides with amino groups at the 5' end were covalently linked onto carboxylic groups of MWCNTs on the electrode. Due to the ability of carbon nanotubes to promote electron-transfer reactions and the high catalytic activity of platinum nanoparticles for chemical reaction, the sensitivity of presented electrochemical DNA biosensor was remarkably improved.

\subsubsection{Metal-Oxide Nanoparticles}

Zirconia $\left(\mathrm{ZrO}_{2}\right)$ is a thermally stability, chemically inert, non- toxicity inorganic oxide with affinity for the groups containing oxygen, and therefore it is an ideal candidate material for immobilization of biomolecules containing oxygen or phosphate groups. Thus, $\mathrm{ZrO}_{2}$ is an ideal material for immobilization of DNA. Zhu et al. [39] electrodynamically deposited $\mathrm{ZrO}_{2}$ thin films onto the bare gold electrode by cycling the potential between -1.1 and $+0.7 \mathrm{~V}$ (versus $\mathrm{Ag} / \mathrm{AgCl}$ ) at a scan rate of $20 \mathrm{mV} / \mathrm{s}$. Oligonucleotide probes with phosphate group at the $5^{\prime}$ end were attached onto the $\mathrm{ZrO}_{2}$ thin films. Yang et al. $[36,40]$ also used $\mathrm{ZrO}_{2}$ coupled with carbon nanotubes to improve DNA attachment to the electrode.

Praseodymium oxide $\left(\operatorname{Pr}_{6} \mathrm{O}_{11}\right)$ has many unique properties, such as a high dielectric constant, a large band gap, high electron affinity, and it is also relatively easy to present as a thin film. Shrestha et al. [41] developed a method for the chemical attachment of thiol-modified oligonucleotides on a $\operatorname{Pr}_{6} \mathrm{O}_{11}$ surface. $\operatorname{Pr}_{6} \mathrm{O}_{11}$ was deposited on a tin-doped indium oxide (ITO) surface to form an ultrathin layer with a larger internal surface area, and then the thiol-modified oligonucleotide attached to an amine-modified $\operatorname{Pr}_{6} \mathrm{O}_{11}$ surface.

\subsubsection{Silicon Nanoparticles}

There are also a few reports concerning nonmetallic nanoparticles as substrates for DNA attachment, mainly focused on silicon nanoparticles. Zhang et al. [42] constructed a biocompatible and uniform interface based on silica nanoparticles derivatized with amino groups for the effective immobilization and sensitive sequence-specific detection of calf thymus DNA. Atomic force microscopy (AFM) and scanning electron microscopy (SEM) results showed that a monolayer of silica nanoparticles can be formed on a gold electrode using cysteine self-assembly monolayer as binder medium. Quantitative results demonstrated that enhanced immobilization of ssDNA up to $1.6 \times 10^{-8} \mathrm{~mol} / \mathrm{cm}^{2}$ could be achieved owing to the larger surface area and the special properties of silica nanoparticles. Wei and 
Wang [43] also prepared a ruthenium $(\mathrm{Ru})$ doped silica nanoparticle modified indium tin oxide electrode by electrostatic self-assembly technique.

\subsection{Nanotubes}

Carbon nanotubes (CNTs) were first noticed and characterized in 1991 by Iijima [44] of NEC Corporation in Japan. CNTs are a new allotrope of carbon originated from fullerene family, which can be described as a graphite sheet rolled up into a nanoscale-tube (which are single-wall carbon nanotubes, SWCNTs), or with additional grapheme tubes around the core of an SWCNT (which are multi-wall CNTs, MWCNTs) [45]. MWCNTs consist of two or more concentric cylindrical shells of graphene sheets coaxially arranged around a central hollow area with spacing between the layers which is close to that of the interlayer separation as in graphite $(0.34 \mathrm{~nm})$. In contrast, SWCNT are made of single grapheme (one layer of graphite) cylinders and have a very narrow size distribution (1-2 nm). Both types of nanotubes have the physical characteristics of solids and are microcrystals, although their diameters are close to molecular dimensions. CNTs offer unique electronic and mechanical properties combined with chemical stability. Combining a biological compound with CNT to monitor a biochemical event resulted in promising biosensors. Due to their catalytic effects, the DNA-end attachment via covalent linkage to the CNTs surface has been demonstrated (as shown in Figure 2) and further extended for the hybridization of the captured strands to their complementary target sequences. CNTs as sensing surfaces for nucleic acids detection have been extensively demonstrated.

Figure 2. Schematic representation of CNTs as substrates for DNA attachment.

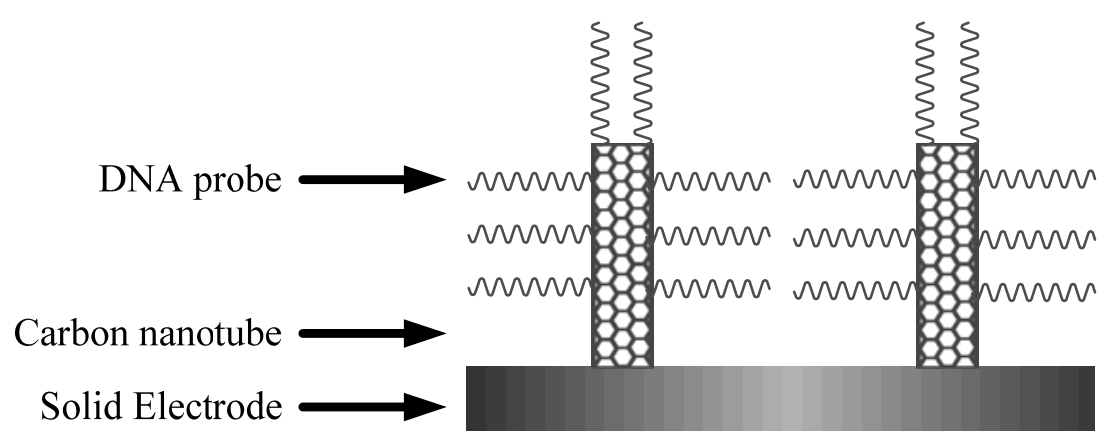

\subsubsection{Direct Attachment of DNA to Functionalized CNTs}

Tang et al. [46] modified the gold electrodes by carboxylic group-functionalized CNTs which activated using $N$-ethyl- $N$ '-(3-dimethylaminopropyl) carbodiimide (EDC) and $N$-hydroxysuccinimidobiotin (NHS), then the synthesized ssDNA was covalently immobilized on the CNTs modified gold electrodes. Abdullin et al. [47] modified glassy-carbon electrodes (GCEs) with preoxidized CNTs. According to the data of atomic force microscopy, the layers of CNTs on GCEs possess a homogeneous nanostructurized surface. Guanine and deoxyguanosine monophosphate could be strongly adsorbed on GCE/CNT and oxidized at +690 and $+930 \mathrm{mV}(\mathrm{pH} 7.0)$, respectively. Similar 
attachment of DNA onto CNTs was also reported by Kerman et al. [48], Erdem et al. [49] and Liang et al. [50].

\subsubsection{Indirect Attachment of DNA through Different Polymers}

Polypyrrole (PPy) is a common material which acts as a bridge to connect DNA with CNTs. $\mathrm{Xu}$ et al. [51,52] reported the attachment of DNA to MWCNTs using PPy. The immobilization relied on the doping of nucleic acid probes within electropolymerized PPy film onto a carboxylic groupfunctionalized MWCNTs (MWNTs-COOH) modified electrode. Oligonucleotide probes served as the solo counter anions during the growth of conducting PPy film on the carbon nanotube modified electrode. Cai et al. [53] and Qi et al. [54] also reported DNA biosensors using electrodes assembled by CNTs and immobilizing DNA probe within PPy.

Chitosan is another material used as a bridge for DNA attachment to CNTs. Li et al. [55] fabricated a biosensor based on chitosan doped with CNTs. It was found that CNTs could enhance the electroactive surface area threefold $\left(0.28 \pm 0.03\right.$ and $0.093 \pm 0.06 \mathrm{~cm}^{2}$ for chitosan-CNTs-modified electrodes and chitosan-modified electrodes, respectively). Bollo et al. [56] also dispersed CNTs in chitosan to modify glassy carbon electrodes (GCE), and obtained an approving result.

Other materials used for DNA attachment to CNTs were also reported. Guo et al. [57] described a method of DNA immobilization on CNTs through amidation. DNAs were covalently immobilized on MWCNTs via diimide-activated amidation between the carboxylic acid groups on the carbon nanotubes and the amino groups on DNA bases. Similarly, Jung et al. [58] covalently immobilized DNA oligonucleotides to prepatterned SWCNT multilayer films by amidation. Guo et al. [59] studied the electrostatic assembly of calf thymus DNA on MWCNTs modified gold electrode via poly (diallyldimethylammonium chloride) (PDDA), a cationic polyelectrolyte. They found that the electrode modified with MWCNTs had significantly enhanced the effective electrode surface area in addition to providing negatively charged groups for the electrostatic assembly of cationic polyelectrolyte.

\subsection{Nanowires}

Nanowires fabricated by polyaniline were utilized as substrates for DNA attachment in some literatures [60,61]. Nanowires of conducting polymers were directly synthesized through electrochemical deposition procedure in an aniline-containing electrolyte solution using the glassy carbon electrode (GCE) as the working electrode. The diameter of the nanowires ranged from 80 to $100 \mathrm{~nm}$. Oligonucleotides with phosphate groups at the 5' end were covalently linked onto the amino groups of polyaniline nanowires on the electrode in the presence of the water-soluble coupling reagent EDC.

Nebel et al. [62] introduced a novel biosensing platform by combination of a) geometrically controlled DNA bonding using vertically aligned diamond nano-wires and b) the superior electrochemical sensing properties of diamond as transducer material. Ultra-hard vertically aligned diamond nano-wires were electrochemically modified to bond phenyl linker-molecules to their tips which provided mesospacing for DNA molecules on the transducer. The nano-wires were generated by 
reactive ion etching of metallically boron doped atomically smooth single crystalline CVD diamond. Electro- and bio-chemical sensor properties reveal sensitivities of $2 \mathrm{pM}$ on $3 \mathrm{~mm}^{2}$ sensor areas and superior DNA bonding stability over 30 hybridization/denaturation cycles.

\subsection{Nanoclusters}

Nanoclusters also reported as substrates for DNA attachment. Zhu et al. [63] synthesized a CdS nanocluster directly with free carboxyl groups on its surface in aqueous solution. Because of the free carboxyl groups on the nanocluster surface, the CdS nanocluster enables it to be easily bonded to amino-group capped oligonucleotides. The assay relied on the hybridization of the target DNA with the CdS nanocluster oligonucleotide DNA probe, followed by the dissolution of the CdS nanoclusters anchored on the hybrids and the indirect determination of the dissolved cadmium ions by sensitive anodic stripping voltammetry (ASV) at a mercury-coated glassy carbon electrode (GCE). The combination of the large number of cadmium ions released from each dsDNA hybrid with the remarkable sensitivity of the electrochemical stripping analysis for cadmium at mercury-film GCE allowed detection of the complementary sequence of DNA at levels as low as $0.2 \mathrm{pmol} / \mathrm{L}$.

\section{Nano-Materials as Signal Amplifier for Hybridization}

When we detect small-molecule ligands of biomedical interest, ligand binding may not significantly perturb the biosensor interface. In this situation, signal amplification may be useful. Signal amplification by labeling the analyte with nano-materials has been reported for DNA biosensors in many literatures.

Figure 3. Schematic representation of nanoparticles as signal amplifiers for hybridization.

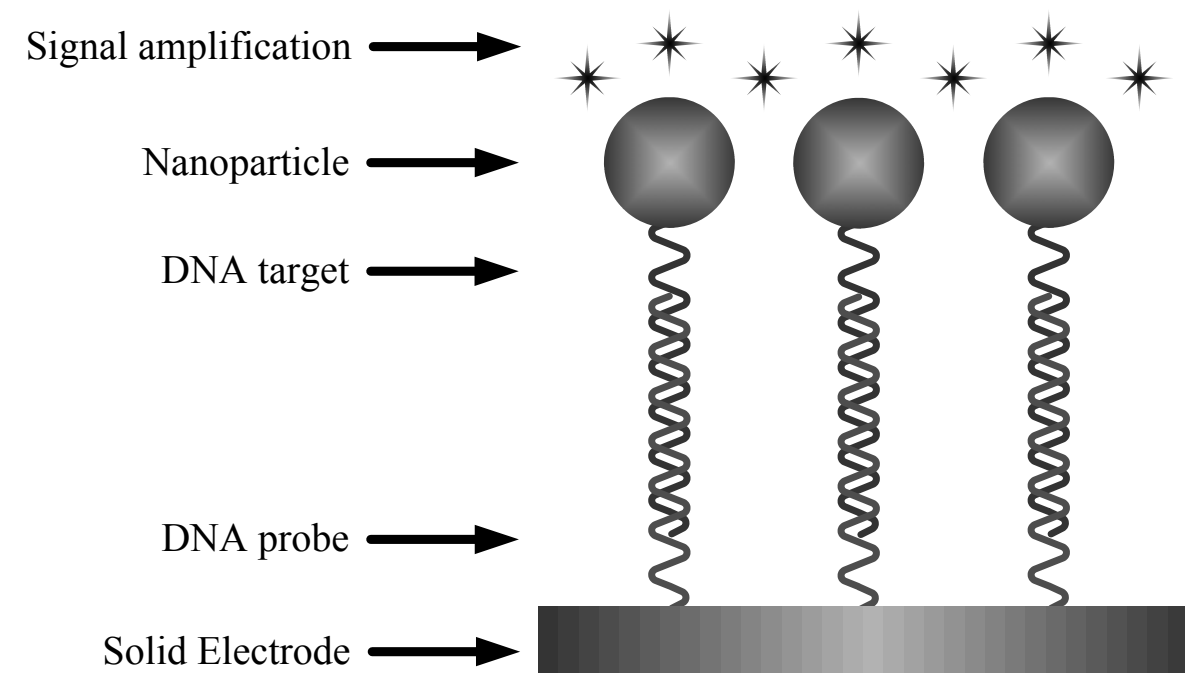

\subsection{Nanoparticles}

Figure 3 shows the schematic representation of nanoparticles as signal amplifier for hybridization. The materials of nanoparticles used as signal amplifier which reported in literatures include gold (Au), 
silver (Ag), cadmium sulfide (CdS). These nanoparticles are summarized for their use in DNA biosensors as follows.

\subsubsection{Gold Nanoparticles}

Due to their electrochemical properties, Au nanoparticles have been used as signal amplifiers in many electrochemical DNA biosensors. Wang et al. [64] demonstrated that Au nanoparticles could amplify the electrochemical impedance and capacitance signals for the model fluorescein/ antifluorescein system. Following immobilization of fluorescein onto Au through formation of a selfassembled monolayer, goat antifluorescein conjugated with $10 \mathrm{~nm}$ Au nanoparticles was introduced into the system. This resulted in an increase in the capacitance similar to $400 \mathrm{nF} / \mathrm{cm}^{2}$, whereas no change could be observed for goat antifluorescein without the Au nanoparticle conjugate. This allowed construction of high-sensitivity electrochemical impedance biosensors at a single low frequency, where the signal was sensitive to the interfacial $\mathrm{R}_{\mathrm{ct}}$. This change in the electrochemical impedance signal of binding to goat antifluorescein conjugated with Au nanoparticles could be attributed to the much higher electrochemical activity of $\mathrm{Au}$ surfaces relative to the underlying organic layer. Amplification of voltammetric signal was also characterized by many researchers [65-67]. Li and $\mathrm{Hu}$ [68] developed an electrochemical determination method for analyzing sequence-specific DNA using ferrocene-capped gold nanoparticles/streptavidin conjugates. Thiolated DNA probes were covalently immobilized on a gold electrode with hexanethiol (HT) forming mixed self-assembled monolayer and hybridized with target DNA, containing a complementary sequence. Duplex (doublestranded) DNA formed on the gold surface. Then functional gold nanoparticles were introduced via strong interaction effect between biotin and streptavidin. The electrochemical signal of ferrocene covering on the gold nanoparticles enhanced obviously in cyclic voltammetry (CV) and differential pulse voltammetry (DPV).

Optical properties of Au nanoparticles were also used for optical DNA biosensor. Yao et al. [69] used Oligonucleotide (ODN)-capped Au nanoparticles in a sandwich assay of ODN or polynucleotide by a flow injection surface plasmon resonance (SPR). A carboxylated dextran film was immobilized onto the SPR sensor surface to eliminate nonspecific adsorption of ODN-capped Au-NPs. The tandem use of signal amplification via the adlayer of the ODN-capped Au-NPs and the differential signal detection by the bicell detector on the SPR resulted in a remarkable DNA detection level. Optical signal amplification by $\mathrm{Au}$ nanoparticles was also reported by Kalogianni et al. [70] and Martins et al. [71].

$\mathrm{Au}$ nanoparticles were also reported to be used as signal amplifiers for quartz crystal microbalance (QCM) biosensors [2,72-75]. Au nanoparticles were attached to the quartz crystal Au electrodes via different methods to increase the mass on the electrode surface, amplifying the signal of hybridization.

\subsubsection{Silver Nanoparticles}

Ag nanoparticles have desirable compositions as oligonucleotides labels in electrochemical detection assays because Ag nanoparticles exhibit better electrochemical activity than Au ones. Cai et al. [76] reported an electrochemical DNA hybridization detection assay, using Ag nanoparticles as the 
oligonucleotide labeling tag. The assay relied on the hybridization of the target DNA with the Ag nanoparticle-oligonucleotide DNA probe, followed by the release of the Ag metal atoms anchored on the hybrids by oxidative metal dissolution. The result indicated that the electrochemical redox reaction of Ag carried out at a low potential, under $0.4 \mathrm{~V}$, and it gave a well-defined sharp voltammetric peak. The oxidative peak of Ag colloid was approximately 100 times as large as that for Au colloid of the same size and amount. And $\mathrm{Ag}$ metal could be easily oxidized to the soluble ionic $\mathrm{Ag}^{+}$with concentrated $\mathrm{HNO}_{3}$ then released from the hybrids, but complete dissolution of a gold tag required more severe conditions ( $1 \mathrm{M} \mathrm{HBr}$ containing $0.1 \mathrm{mM} \mathrm{Br}_{2}$ ) and the electrode might be damaged in this medium. Similar electrochemical characterizations of Ag nanoparticles used in DNA biosensors were done by Fu et al. [77] and K'Owino et al. [78].

\subsubsection{Cadmium Sulfide Nanoparticles}

Cadmium sulfide (CdS) nano-material is a semiconductor material with attractive electrochemical properties. $\mathrm{CdS}$ as oligonucleotide labeling tags for detection of DNA hybridization have been reported by several researchers. Xu et al. [79] used a type of CdS nanoparticles covalently binding with the amine groups modified target ssDNA to enhance the electrochemical impedance spectroscopy (EIS) signal. Because of the negative charges, space resistance and semiconductor characteristics of CdS tags, the use of CdS nanoparticle greatly improved DNA hybridization detection sensitivity. Peng et al. [80] also used CdS nanoparticles to enhance the EIS signal. They described an ODN sensor based on electropolymerization of a conducting polymer (polypyrrole) in the presence of a sample containing $\mathrm{ODN}(\mathrm{s})$. The resulting trapped $\mathrm{ODN}(\mathrm{s})$ were then probed by addition of complimentary sequence ODN. By incorporating CdS nanoparticles with the probe, a significant improvement in sensor sensitivity was observed.

\subsection{Nanotubes}

The conductive properties of CNTs suggest that they could mediate electron transfer reactions and enhance the relative electrochemical reactivity with electroactive species in solution when used as the electrode material or substrates modified on solid electrodes. As electrode or substrates modified materials, CNTs show better electrochemical behavior than traditional glass carbon electrodes, carbon paste electrodes and any other carbon electrodes [81]. Therefore, part of the previous introduction of CNTs used as substrates for DNA attachment in electrochemical biosensors could also be regarded as electrochemical signal amplifier. The guanine oxidation signal of double stranded calf-thymus DNA after 3 min accumulation was 20 times higher at a CNTs modified glass carbon electrodes cross-linked with glutaraldehyde (GTA) than at a bare GCE using differential pulse voltammetry, while the peak potential was around $45 \mathrm{mV}$ less positive. And the guanine oxidation signal demonstrated to be highly reproducible, with 3.4\% RSD for five different electrodes [56]. Zhang et al. [82] compared the electrochemical behavior of $\mathrm{K}_{3} \mathrm{Fe}(\mathrm{CN})_{6}$ at a bare glassy carbon electrode and an electrochemically activated glassy carbon electrode which was treated in the absence or presence of multi-walled CNTs under identical experimental conditions. The results indicate that the electrochemical response of the $\mathrm{K}_{3} \mathrm{Fe}(\mathrm{CN})_{6}$ at the CNTs activated electrode was the strongest among these three kinds of electrodes. 
The unique optical properties make CNTs ideal optical probes for tagging biomolecules. CNTs exhibit strong Raman signals as well as fluorescence emissions in the near infrared region. And such signals do not blink or photobleach under prolonged excitation, which is an advantage in optical nanobiomarker applications. The intense Raman scattering from CNTs provides a large amount of information about the structure and properties of nanotubes with some of the highest known crosssections for single molecules. Hwang et al. [83] presented single-stranded DNA conjugated SWCNT probes to locate a particular sequence of DNA within a complex genome. Chromosomal DNAs of human fibroblasts and Escherichia coli were used as a target and a control, respectively. Southern blotting, which used photostable Raman signals of nanotubes instead of fluorescent dyes, demonstrated excellent sensitivity and specificity of the probes. Their results showed that SWCNTs may be used as generic nano-biomarkers for the precise detection of specific kinds of genes. Cao et al. [84] developed SWCNT-based molecular probes by conjugating single-stranded DNA (ssDNA) with SWCNT. The results showed that SWCNTs exhibited sharp absorption peak distributions in the UV-vis-NIR range when they were individually dispersed in aqueous solution medium. DNA hybridization on the sidewall of SWCNT resulted in systematic red shifts of the absorption spectra of semiconducting nanotubes. This research demonstrated that ssDNA-SWCNTs probes might be used to detect specific kinds of DNA oligonucleotides as optical nano-biosensors.

Recently, CNTs have also been utilized as a novel support material to concentrate nanoparticles or enzyme molecules on it as a more powerful DNA hybridization indicator than using a single nanoparticle or enzyme molecule indicating DNA hybridization (as shown in Figure 4). Wang et al. [67] described an effective method for amplifying electrical detection of DNA hybridization based on CNTs carrying a large number of CdS particle tracers. Such use of CNT amplification platforms was combined with an ultrasensitive stripping voltammetric detection of the dissolved CdS tags following dual hybridization events of a sandwich assay on a streptavidin modified 96-well microplate. Anchoring of the monolayer-protected quantum dots to the acetone-activated CNT was accomplished via hydrophobic interactions. SEM images indicated that the nanocrystals were attached along the CNT sidewall, with a loading of around 500 particles per CNT. A substantial ( 500 fold) lowering of the detection limit was obtained compared to conventional single particle stripping hybridization assays, reflecting the CdS loading on the CNT carrier. A large excess ( 250 fold) of non-complimentary oligonucleotides had minimal effect on the response. They also demonstrated the use of CNTs for dramatically amplifying enzyme-based bioaffinity electrical sensing DNA [85]. In the new bioaffinity assays, CNTs played a dual amplification role in both the recognition and transduction events, namely as carriers for numerous enzyme tags and for accumulating the product of the enzymatic reaction. Such coupling of several CNT-derived amplification processes led to the low detection limit. Li et al. [86] developed an ultrasensitive electrogenerated chemilummescence (ECL) detection method of DNA hybridization based-on SWCNT carrying a large number of ruthenium complex tags. The probe of single strand DNA (ssDNA) and ruthenium complex were loaded at SWCNT, which was taken as an ECL probe. When the capture ssDNA with a thiol group was self-assembled onto the surface of gold electrode, and then hybridized with target ssDNA and further hybridized with the ECL probe to form DNA sandwich conjugate, a strong ECL response was electrochemically generated. Lee et al. [13] demonstrated a method of highly sensitive colorimetric detection of target DNA sequences amplified by the novel CNT-based label. Atomic force microscope (AFM) images confirmed that a monolayer of 
horseradish peroxidase and detection probe molecules was immobilized along the carboxylated CNT carrier. The resulting CNT labels significantly enhanced the nucleic acid assay sensitivity by at least 1000 times compared to that of conventional labels used in enzyme-linked oligosorbent assay (ELOSA).

Figure 4. Schematic representation of nanotubes as signal amplifiers for hybridization.

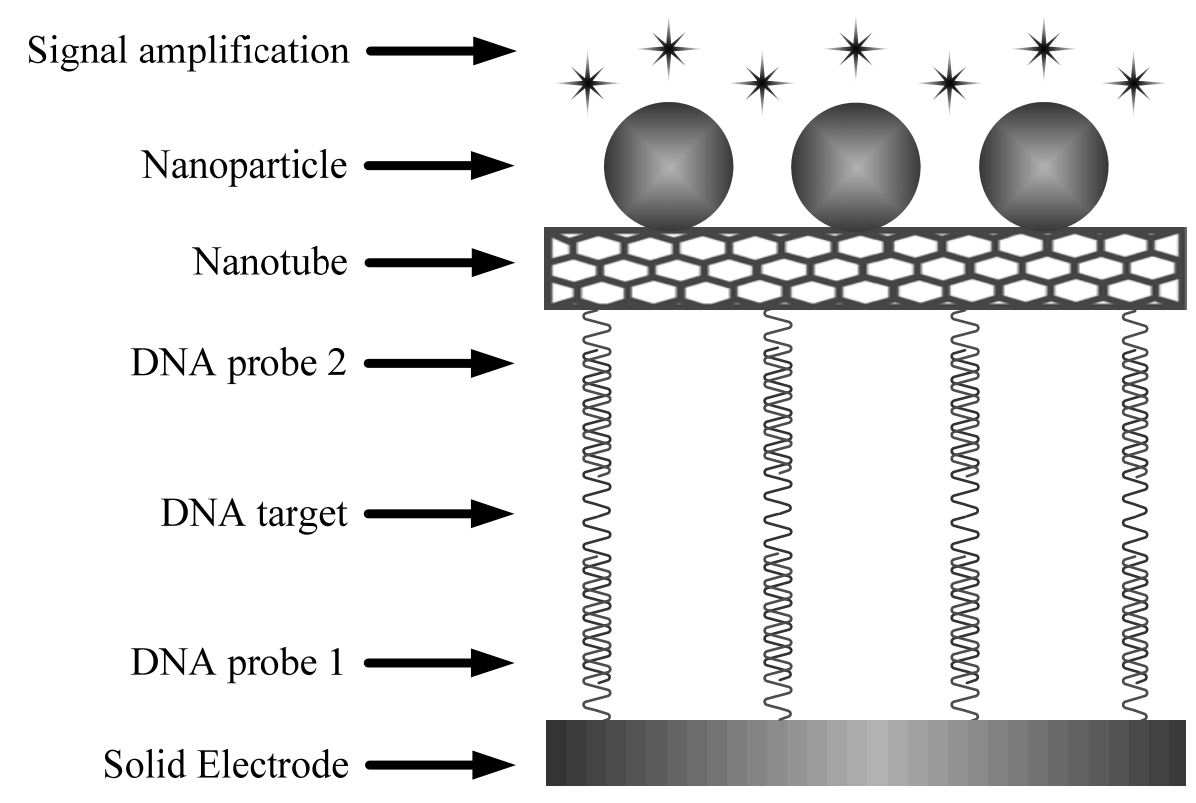

\subsection{Nanowires}

Gao et al. [87] fabricated arrays of highly ordered silicon nanowires using complementary metaloxide semiconductor compatible technology and investigated their applications in biosensors. Peptide nucleic acid (PNA) capture probe-functionalized silicon nanowires arrays showed a concentrationdependent resistance change upon hybridization to complementary target DNA that is linear over a large dynamic range with a detection limit of $10 \mathrm{fM}$. As with other silicon nanowires biosensing devices, the sensing mechanism can be understood in terms of the change in charge density at the silicon nanowires surface after hybridization, the so-called "field effect". The silicon nanowires array biosensor discriminated satisfactorily against mismatched target DNA.

\subsection{Nanoclusters}

$\mathrm{Hu}$ et al. [88] developed a novel surface plasmon resonance (SPR) biosensor which used a cosputtering method utilizing a multi-target sputtering system to fabricate the dielectric films $\left(\mathrm{SiO}_{2}\right)$ with embedded Au nanoclusters. It was shown that the sensitivity of the SPR biosensor could be improved by adjusting the size and volume fraction of the embedded Au nanoclusters in order to control the surface plasmon effect. The DNA hybridization experimental results could achieve 10-fold improvement in the resolution performance compared with the conventional SPR biosensors. 


\section{Conclusions and Future Prospects}

In conclusion, different nano-materials have been successfully applied to DNA biosensors as substrates for DNA attachment and as labels for signal amplification, specifically. Table 1 lists part of the recent reports on the use of nano-materials to improve DNA biosensors.

Table 1. Recent reports of nano-materials used in DNA biosensors.

\begin{tabular}{|c|c|c|c|c|c|c|c|}
\hline Author & Form & Material & Size & $\begin{array}{c}\text { Detection } \\
\text { Method }\end{array}$ & Purpose & Effect & Reference \\
\hline $\begin{array}{c}\text { Baca, } \\
\text { Zhou et } \\
\text { al. } 2004\end{array}$ & Particle & $\begin{array}{l}\text { Ferrocene- } \\
\text { capped Au } \\
\text { nanoparticle }\end{array}$ & $10 \mathrm{~nm}$ & Voltammetry & $\begin{array}{c}\text { Signal } \\
\text { amplification }\end{array}$ & $\begin{array}{l}\text { The detection level } \\
\text { for glutathione was } \\
1 \mathrm{nM}\end{array}$ & {$[65]$} \\
\hline $\begin{array}{l}\text { Bollo, } \\
\text { Ferreyra } \\
\text { et al. } \\
2007\end{array}$ & Tube & MWCNT & $\begin{array}{c}1-5 \mu \mathrm{m} \text { long and } \\
(30 \pm 15) \mathrm{nm} \\
\text { diameter }\end{array}$ & Voltammetry & $\begin{array}{l}\text { Substrates for } \\
\text { DNA } \\
\text { attachment }\end{array}$ & $\begin{array}{l}\text { The guanine } \\
\text { oxidation signal of } \\
\text { double stranded } \\
\text { DNA after 3-min } \\
\text { accumulation was } \\
20 \text { times higher } \\
\text { than at bare GCE }\end{array}$ & {$[56]$} \\
\hline $\begin{array}{c}\text { Cao, } \\
\text { Kim et } \\
\text { al. } 2008\end{array}$ & Tube & SWCNT & $\begin{array}{c}\text { Diameter: } 0.7-1.1 \\
\text { nm, average } \\
\text { length: } 1 \mu \mathrm{m}\end{array}$ & $\begin{array}{l}\text { UV-VIS-NIR } \\
\text { absorption } \\
\text { spectra }\end{array}$ & $\begin{array}{l}\text { Substrates for } \\
\text { DNA } \\
\text { attachment }\end{array}$ & $\begin{array}{l}\text { DNA hybridization } \\
\text { on the sidewall of } \\
\text { SWCNT resulted in } \\
\text { systematic red } \\
\text { shifts of the } \\
\text { absorption spectra } \\
\text { of semiconducting } \\
\text { nanotubes }\end{array}$ & [84] \\
\hline $\begin{array}{c}\text { Chen, } \\
\text { Wu et al. } \\
2008\end{array}$ & Particle & $\mathrm{Au}$ & $\begin{array}{l}\text { Average diameter: } \\
\qquad 20 \mathrm{~nm}\end{array}$ & $\begin{array}{l}\text { Circulating- } \\
\text { flow QCM }\end{array}$ & $\begin{array}{c}\text { Signal } \\
\text { amplification }\end{array}$ & $\begin{array}{l}\text { Effectively } \\
\text { amplified the } \\
\text { signals in } \\
\text { frequency change }\end{array}$ & [2] \\
\hline $\begin{array}{c}\text { Fu, Yuan } \\
\text { et al. } \\
2005\end{array}$ & Particle & $\mathrm{Au}$ & $16 \mathrm{~nm}$ & EIS & $\begin{array}{l}\text { Substrates for } \\
\text { DNA } \\
\text { attachment }\end{array}$ & $\begin{array}{l}\text { Detection limit: } \\
5.0 \times 10^{-9} \mathrm{M}\end{array}$ & {$[26]$} \\
\hline $\begin{array}{l}\text { Gao, } \\
\text { Agarwal } \\
\text { et al. } \\
2007 \\
\end{array}$ & wire & Silicon & $50-80 \mathrm{~nm}$ & $\begin{array}{c}\text { Electrical } \\
\text { measurements }\end{array}$ & $\begin{array}{l}\text { Substrates for } \\
\text { DNA } \\
\text { attachment }\end{array}$ & $\begin{array}{l}\text { Detection limit: } \\
10 \mathrm{fM}\end{array}$ & [87] \\
\hline
\end{tabular}


Table 1. Cont.

\begin{tabular}{|c|c|c|c|c|c|c|c|}
\hline $\begin{array}{l}\text { Ghanbari, } \\
\text { Bathaie et } \\
\text { al. } 2008\end{array}$ & Wire & Polypyrrole & $\begin{array}{l}30-90 \mathrm{~nm} \text { in } \\
\text { diameter }\end{array}$ & $\begin{array}{c}\text { SEM \& EIS \& } \\
\text { Voltammetry \& } \\
\text { FTIR spectroscopy }\end{array}$ & $\begin{array}{l}\text { Substrates for } \\
\text { DNA } \\
\text { attachment }\end{array}$ & $\begin{array}{l}\text { A binding } \\
\text { constant value of } \\
4.08 \times 10^{5} \\
\pm 0.05 \mathrm{M}^{-1} \text { was } \\
\text { obtained. }\end{array}$ & [89] \\
\hline $\begin{array}{l}\text { Hu, Chen } \\
\text { et al. } 2004\end{array}$ & Cluster & $\mathrm{Au} \& \mathrm{SiO}_{2}$ & $4.0 \mathrm{~nm}$ & SPR & $\begin{array}{c}\text { Signal } \\
\text { amplification }\end{array}$ & $\begin{array}{l}10 \text {-fold } \\
\text { improvement in } \\
\text { the resolution } \\
\text { performance }\end{array}$ & {$[88]$} \\
\hline $\begin{array}{c}\text { Kalogianni, } \\
\text { Koraki et } \\
\text { al. } 2006\end{array}$ & Particle & $\mathrm{Au}$ & & $\begin{array}{c}\text { Dry-reagent visual } \\
\text { detection }\end{array}$ & $\begin{array}{c}\text { Signal } \\
\text { amplification }\end{array}$ & $\begin{array}{l}\text { Detection limit: } \\
0.16 \mathrm{nM}\end{array}$ & {$[70]$} \\
\hline $\begin{array}{c}\text { Kang, Li et } \\
\text { al. } 2007\end{array}$ & Particle & $\mathrm{Au}$ & & Voltammetry \& EIS & $\begin{array}{c}\text { Substrates for } \\
\text { DNA } \\
\text { attachment }\end{array}$ & $\begin{array}{l}\text { detection limit } \\
\text { could reach the } \\
\text { concentration of } \\
10 \times 10^{-9} \mathrm{M}\end{array}$ & {$[27]$} \\
\hline $\begin{array}{l}\text { Kerman, } \\
\text { Morita et } \\
\text { al. } 2004\end{array}$ & Tube & MWCNT & $\begin{array}{l}\text { 10-20 nm i.d. } \\
\text { and } 1-5 \mu \mathrm{m} \\
\text { length }\end{array}$ & $\begin{array}{c}\text { Square-wave } \\
\text { voltammetry \& UV- } \\
\text { visible } \\
\text { spectrophotometer }\end{array}$ & $\begin{array}{l}\text { Substrates for } \\
\text { DNA } \\
\text { attachment }\end{array}$ & $\begin{array}{l}\text { Detection limit: } \\
10 \mathrm{pg} / \mathrm{mL}\end{array}$ & {$[90]$} \\
\hline $\begin{array}{l}\text { Lee, Ye et } \\
\text { al. } 2007\end{array}$ & Tube & SWCNT & & $\begin{array}{c}\text { AFM \& } \\
\text { Colorimetric } \\
\text { detection }\end{array}$ & $\begin{array}{c}\text { Substrates for } \\
\text { HRP-DP }\end{array}$ & $\begin{array}{l}\text { Enhanced } \\
\text { sensitivity by at } \\
\text { least } 1000 \text { times, } \\
\text { and detection } \\
\text { limit: } 1 \times 10^{-12} \mathrm{M}\end{array}$ & {$[13]$} \\
\hline $\begin{array}{l}\text { Li, Liu et } \\
\text { al. } 2005\end{array}$ & Tube & MWCNT & & $\begin{array}{l}\text { CV \& UV-visible } \\
\text { spectrophotometric }\end{array}$ & $\begin{array}{c}\text { Substrates for } \\
\text { DNA } \\
\text { attachment }\end{array}$ & $\begin{array}{l}\text { Enhance the } \\
\text { electroactive } \\
\text { surface area } \\
\text { threefold }\end{array}$ & {$[55]$} \\
\hline $\begin{array}{l}\text { Lu, Lin et } \\
\text { al. } 2007\end{array}$ & $\begin{array}{c}\text { Hollow } \\
\text { ball }\end{array}$ & $\mathrm{Au}$ & $3.5 \mathrm{~nm}$ & AFM \& QCM & $\begin{array}{c}\text { Substrates for } \\
\text { DNA } \\
\text { attachment }\end{array}$ & $\begin{array}{l}\text { Detected limit is } \\
\text { extend from } 10^{-9} \\
\text { to } 10^{-12} \mathrm{M}\end{array}$ & {$[30]$} \\
\hline $\begin{array}{l}\text { Nebel, } \\
\text { Yang et al. } \\
2008\end{array}$ & Wire & Diamond & $10 \mathrm{~nm}$ diameter & $\begin{array}{c}\text { AFM \& SEM \& EIS } \\
\text { \& Voltammetry }\end{array}$ & $\begin{array}{c}\text { Substrates for } \\
\text { DNA } \\
\text { attachment }\end{array}$ & $\begin{array}{l}\text { The sensitivity of } \\
2 \mathrm{pM} \text { on } 3 \mathrm{~mm}^{2} \\
\text { sensor areas and } \\
\text { superior DNA } \\
\text { bonding stability } \\
\text { over } 30 \\
\text { hybridization/ } \\
\text { denaturation } \\
\text { cycles. }\end{array}$ & {$[62]$} \\
\hline
\end{tabular}


Table 1. Cont.

\begin{tabular}{|c|c|c|c|c|c|c|c|}
\hline $\begin{array}{c}\text { Peng, } \\
\text { Soeller et } \\
\text { al. } 2006\end{array}$ & Particle & $\mathrm{CdS}$ & $\begin{array}{c}\text { Average } \\
\text { diameter: } 10 \\
\mathrm{~nm}\end{array}$ & EIS \& Voltammetry & $\begin{array}{c}\text { Signal } \\
\text { amplification }\end{array}$ & $\begin{array}{l}\text { Increase in } \\
\text { electron-transfer } \\
\text { resistance per } \\
\text { CdS-ODN bound } \\
\text { is } 500 \text { times larger } \\
\text { than the increase } \\
\text { per unlabeled } \\
\text { ODN-probe } \\
\text { bound. }\end{array}$ & {$[80]$} \\
\hline $\begin{array}{l}\text { Qi, Li et al. } \\
\quad 2007\end{array}$ & Tube & MWCNT & & SEM \& DPV & $\begin{array}{c}\text { Substrates for } \\
\text { DNA } \\
\text { attachment }\end{array}$ & $\begin{array}{l}\text { Detection limit: } \\
8.5 \times 10^{-11} \mathrm{M}\end{array}$ & {$[54]$} \\
\hline $\begin{array}{l}\text { Sun, Choy } \\
\text { et al. } 2009\end{array}$ & Particle & $\mathrm{Ag}$ & & QCM \& EIS & $\begin{array}{c}\text { Substrates for } \\
\text { DNA } \\
\text { attachment }\end{array}$ & $\begin{array}{l}\text { Enhancement of } \\
3.3 \text { times for } \\
\text { binding of } \\
\text { complementary } \\
\text { DNA has been } \\
\text { shown }\end{array}$ & {$[3]$} \\
\hline $\begin{array}{c}\text { Tsai, } \\
\text { Chang et } \\
\text { al. } 2006\end{array}$ & Particle & $\mathrm{Au}$ & & $\begin{array}{c}\text { FESEM \& } \\
\text { Voltammetry }\end{array}$ & $\begin{array}{c}\text { Substrates for } \\
\text { DNA } \\
\text { attachment }\end{array}$ & $\begin{array}{l}\text { The number } \\
\text { density of the } \\
\text { AuNP spots in the } \\
\text { multi-AuNPs } \\
\text { biosensor is much } \\
\text { higher than that in } \\
\text { the single-AuNPs } \\
\text { biosensor }\end{array}$ & {$[32]$} \\
\hline $\begin{array}{l}\text { Wang, Liu } \\
\text { et al. } 2003\end{array}$ & $\begin{array}{l}\text { Tube \& } \\
\text { Particle }\end{array}$ & $\begin{array}{c}\text { SWCNT \& } \\
\text { CdS }\end{array}$ & $\begin{array}{c}5-10 \mathrm{~nm} \\
\text { diameter \& } 2 \\
\mu \mathrm{m} \text { length }\end{array}$ & $\begin{array}{c}\text { SEM \& Stripping- } \\
\text { voltammetric }\end{array}$ & $\begin{array}{l}\text { SWCNT used } \\
\text { as substrates } \\
\text { for CdS tags }\end{array}$ & $\begin{array}{l}\text { Detection limit: } \\
40 \mathrm{pg} / \mathrm{mL}\end{array}$ & [91] \\
\hline $\begin{array}{l}\text { Xia, Chen } \\
\text { et al. } 2008\end{array}$ & Particle & $\mathrm{CdS}$ & About $600 \mathrm{~nm}$ & $\mathrm{CV}$ & $\begin{array}{c}\text { Substrates for } \\
\text { DNA } \\
\text { attachment }\end{array}$ & $\begin{array}{l}\text { Detection range: } \\
1 \times 10^{-1} \text { to } \\
1 \times 10^{-5} \mu \mathrm{M}\end{array}$ & [92] \\
\hline $\begin{array}{l}\text { Xu, Cai et } \\
\text { al. } 2004\end{array}$ & Particle & $\mathrm{CdS}$ & $\begin{array}{c}\text { Average } \\
\text { diameter: } 5 \mathrm{~nm}\end{array}$ & EIS & $\begin{array}{c}\text { Signal } \\
\text { amplification }\end{array}$ & $\begin{array}{l}\text { Sensitivity is } \\
\text { improved to two } \\
\text { orders of } \\
\text { magnitude } \\
\text { compared with } \\
\text { non-CdS tagged } \\
\text { DNA sequences }\end{array}$ & [79] \\
\hline $\begin{array}{l}\text { Xu, Jiang } \\
\text { et al. } 2004\end{array}$ & Tube & MWCNT & $\begin{array}{c}30-50 \mathrm{~nm} \\
\text { diameter \& 1- } \\
10 \mu \mathrm{m} \text { length }\end{array}$ & EIS \& Voltammetry & $\begin{array}{c}\text { Substrates for } \\
\text { DNA } \\
\text { attachment }\end{array}$ & $\begin{array}{l}\text { Detection limit: } \\
5 \times 10^{-11} \mathrm{M}\end{array}$ & {$[51]$} \\
\hline
\end{tabular}


Table 1. Cont.

\begin{tabular}{|c|c|c|c|c|c|c|c|}
\hline $\begin{array}{c}\text { Yang, } \\
\text { Wang et } \\
\text { al. } 2007\end{array}$ & $\begin{array}{l}\text { Tube \& } \\
\text { Particle }\end{array}$ & $\begin{array}{c}\text { MWCNT \& } \\
\mathrm{ZrO}_{2}\end{array}$ & & $\mathrm{CV}$ & $\begin{array}{c}\text { Substrates for } \\
\text { DNA } \\
\text { attachment }\end{array}$ & $\begin{array}{l}\text { Detection limit: } \\
7.5 \times 10^{-11} \mathrm{M}\end{array}$ & [40] \\
\hline $\begin{array}{l}\text { Yao, Li et } \\
\text { al. } 2006\end{array}$ & Particle & $\mathrm{Au}$ & & SPR & $\begin{array}{c}\text { Signal } \\
\text { amplification }\end{array}$ & $\begin{array}{l}\text { A } 39-\text { mer target at a } \\
\text { quantity as low as } \\
2.1 \times 10^{-20} \mathrm{~mol} \text {, } \\
\text { corresponding to } \\
1.38 \mathrm{fM} \text { in a } 15 \mu \mathrm{L} \\
\text { solution, can be } \\
\text { measured. }\end{array}$ & [69] \\
\hline $\begin{array}{l}\text { Zhang, } \\
\text { Chen et } \\
\text { al. } 2004\end{array}$ & Particle & $\mathrm{SiO}_{2}$ & & $\begin{array}{c}\text { AFM \& SEM \& } \\
\text { X-ray \& } \\
\text { photoelectron } \\
\text { spectroscopy \& } \\
\text { EIS \& } \\
\text { Voltammetry }\end{array}$ & $\begin{array}{c}\text { Substrates for } \\
\text { DNA } \\
\text { attachment }\end{array}$ & $\begin{array}{l}\text { Enhanced } \\
\text { immobilization of ss- } \\
\text { DNA up to } \\
1.6 \times 10^{-8} \mathrm{~mol} / \mathrm{cm}^{2} \text {, } \\
\text { markedly larger than } \\
\text { the commonly } \\
\text { accepted saturation } \\
\text { monolayer adsorption } \\
\left(2.77 \times 10^{-10} \mathrm{~mol} / \mathrm{cm}^{2}\right)\end{array}$ & [42] \\
\hline $\begin{array}{l}\text { Zhang, } \\
\text { Wang et } \\
\text { al. } 2007\end{array}$ & Tube & MWCNT & $30 \mathrm{~nm}$ diameter & $\begin{array}{c}\text { AFM \& } \\
\text { Voltammetry }\end{array}$ & $\begin{array}{l}\text { Substrates for } \\
\text { DNA } \\
\text { attachment }\end{array}$ & $\begin{array}{l}\text { Detection limit of } \\
7.5 \mathrm{nM} \text { for guanine } \\
\text { and } 150 \mathrm{ng} / \mathrm{mL} \text { for } \\
\text { acid denatured DNA }\end{array}$ & [82] \\
\hline $\begin{array}{l}\text { Zhang, } \\
\text { Yang et } \\
\text { al. } 2009\end{array}$ & $\begin{array}{l}\text { Tube \& } \\
\text { shuttle }\end{array}$ & $\begin{array}{c}\text { SWCNT \& } \\
\mathrm{CeO}_{2}\end{array}$ & & $\begin{array}{l}\text { SEM \& EIS \& } \\
\text { Voltammetry }\end{array}$ & $\begin{array}{c}\text { Substrates for } \\
\text { DNA } \\
\text { attachment }\end{array}$ & $\begin{array}{l}\text { The dynamic range } \\
\text { for detecting the } \\
\text { sequence specific } \\
\text { DNA was from } \\
1.0 \times 10^{-12} \mathrm{~mol} / \mathrm{L} \text { to } \\
1.0 \times 10^{-7} \mathrm{~mol} / \mathrm{L} \text {, and } \\
\text { the detection limit } \\
\text { was } 2.3 \times 10^{-13} \mathrm{~mol} / \mathrm{L}\end{array}$ & [93] \\
\hline $\begin{array}{l}\text { Zhu, } \\
\text { Chang et } \\
\text { al. } 2005\end{array}$ & $\begin{array}{l}\text { Tube \& } \\
\text { Particle }\end{array}$ & $\begin{array}{c}\text { MWCNT \& } \\
\text { Pt }\end{array}$ & $\begin{array}{c}40-60 \mathrm{~nm} \\
\text { diameter \& } \\
1-10 \mu \mathrm{m} \text { length }\end{array}$ & CV \& DPV & $\begin{array}{c}\text { Substrates for } \\
\text { DNA } \\
\text { attachment }\end{array}$ & $\begin{array}{l}\text { Detection limit: } \\
1.0 \times 10^{-11} \mathrm{M}\end{array}$ & [38] \\
\hline
\end{tabular}

(1) When nano-materials are used as substrates for DNA attachment, the smaller size the nanomaterial is, the better result a DNA biosensor can provide. As the size of a crystal is reduced, the surface-to-volume ratio of a crystal is increased, thus it can enlarge the electrode surface area to greatly enhance the amount of immobilized DNA. But this conclusion is only applicable under the condition that the shape of nano-materials is regular, otherwise we cannot obtain a repeatable result. Similar conclusion holds true when nano-materials are used as signal amplifiers.

(2) Due to the diverse properties of different nano-materials, utilizing two or more types of nanomaterials could enhance the good qualities as well as offset the insufficiency of each individual nano- 
material, which could produce better results than that using only one type of nano-materials. For example, Cai et al. [94] described an electrochemical detection method for analyzing sequencespecific DNA using gold nanoparticle DNA probes and subsequent signal amplification step by silver enhancement. The assay relied on the electrostatic adsorption of target oligonucleotides onto the sensing surface of the glassy carbon electrode (GCE) and its hybridization to the gold nanoparticlelabeled oligonucleotides DNA probe. After silver deposition onto gold nanoparticles, binding events between the probe and target were monitored by the differential pulse voltammetry (DPV) signal of the large number of silver atoms anchored on the hybrids at the electrode surface. Coupled with this 'nanoparticle-promoted' reduction of silver signal amplification method, the sensitivity of this electrochemical DNA biosensor was increased by approximately two orders of magnitude. Utilizing multiple nano-materials was also reported in some other literatures [95,96], including part of the aforementioned literatures.

(3) Although great efforts have been made in all DNA biosensor technologies in order to eliminate the role of the PCR from their protocols, this goal has not yet been achieved [97]. Many scientists have paid attention to the applications of DNA biosensors in the detection of DNA sequences in real samples, for example, GMO, hepatitis virus and so on [70,98,99], but almost all the protocols could not be achieved without PCR. As the development of nano-technology, nano-materials with smaller size and/or with improved biological and chemical properties would substantially enhance the accuracy, selectivity and sensitivity of DNA biosensors. With the rapid development of both nanotechnology and biosensing technology, it can be envisaged that DNA biosensors without PCR amplification will come true in the near future.

\section{Acknowledgements}

The authors gratefully acknowledge the financial support provided by National Natural Science Foundation of China (No. 30825027) and National Key Technology R\&D Program (No. 2006BAD11A12).

\section{References and Notes}

1. Hejazi, M.S.; Alipour, E.; Pournaghi-Azar, M.H. Immobilization and voltammetric detection of human interleukine-2 gene on the pencil graphite electrode. Talanta 2007, 71, 1734-1740.

2. Chen, S.H.; Wu, V.C.H.; Chuang, Y.C.; Lin, C.S. Using oligonucleotide-functionalized Au nanoparticles to rapidly detect foodborne pathogens on a piezoelectric biosensor. J. Microbiol. Meth. 2008, 73, 7-17.

3. Sun, H.; Choy, T.S.; Zhu, D.R.; Yam, W.C.; Fung, Y.S. Nano-silver-modified PQC/DNA biosensor for detecting E. coli in environmental water. Biosens. Bioelectron. 2009, 24, 1405-1410.

4. Zhang, D.; Alocilja, E.C. Characterization of nanoporous silicon-based DNA biosensor for the detection of Salmonella Enteritidis. IEEE Sens. J. 2008, 8, 775-780.

5. Xia, H.; Wang, F.; Huang, Q.; Huang, J.; Chen, M.; Wang, J.; Yao, C.; Chen, Q.; Cai, G.; Fu, W. Detection of Staphylococcus epidermidis by a quartz crystal microbalance nucleic acid biosensor array using Au nanoparticle signal amplification. Sensors 2008, 8, 6453-6470. 
6. Tichoniuk, M.; Ligaj, M.; Filipiak, M. Application of DNA hybridization biosensor as a screening method for the detection of genetically modified food components. Sensors 2008, 8, 2118-2135.

7. Bogani, P.; Minunni, M.; Tombelli, S.; Buiatti, M.; Mascini, M. Transgenes monitoring in an industrial soybean processing chain by DNA-based conventional approaches and biosensors. Food Chem. 2009, 113, 658-664,

8. Berganza, J.; Olabarria, G.; Garcia, R.; Verdoy, D.; Rebollo, A.; Arana, S. DNA microdevice for electrochemical detection of Escherichia coli O157 : H7 molecular markers. Biosens. Bioelectron. 2007, 22, 2132-2137.

9. Centola, M.; Frank, M.B.; Bolstad, A.I.; Alex, P.; Szanto, A.; Zeher, M.; Hjelmervik, T.O.; Jonsson, R.; Nakken, B.; Szegedi, G.; Szodoray, P. Genome-scale assessment of molecular pathology in systemic autoimmune diseases using microarray technology: a potential breakthrough diagnostic and individualized therapy-design tool. Scand. J. Immunol. 2006, 64, $236-242$.

10. Hendry, L.B.; Mahesh, V.B.; Bransome, E.D.; Ewing, D.E. Small molecule intercalation with double stranded DNA: Implications for normal gene regulation and for predicting the biological efficacy and genotoxicity of drugs and other chemicals. Mutat. Res-Fund Mol. M. 2007, 623, 53-71.

11. Urthaler, J.; Buchinger, W.; Necina, R. Improved downstream process for the production of plasmid DNA for gene therapy. Acta Biochim. Pol. 2005, 52, 703-711.

12. Verschaeve, L.; Koppen, G.; van Gorp, U.; Schoeters, G.; Jacobs, G.; Zwijzen, C. Seasonal variations in spontaneous levels of DNA damage; implication in the risk assessment of environmental chemicals. J. Appl. Toxicol. 2007, 27, 612-620.

13. Lee, A.C.; Ye, J.S.; Tan, S.N.; Poenar, D.P.; Sheu, F.-S.; Heng, C.K.; Lin, T.M. Carbon nanotubebased labels for highly sensitive colorimetric and aggregation-based visual detection of nucleic acids. Nanotechnology 2007, 18, 455102:1-455102:9.

14. Giakoumaki, E.; Minunni, M.; Tombelli, S.; Tothill, I.E.; Mascini, M.; Bogani, P.; Buiatti, M. Combination of amplification and post-amplification strategies to improve optical DNA sensing. Biosens. Bioelectron. 2003, 19, 337-344.

15. Weller, H. Quantized semiconductor particles: a novel state of matter for materials science. Adv. Mater. 1993, 5, 88-95.

16. Henglein, A. Q-particles: size quantization effects in colloidal semiconductors. Progr. Colloid Polymer Sci. 1987, 73, 1-3.

17. Templeton, A.C.; Wuelfing, M.P.; Murray, R.W. Monolayer protected cluster molecules. Accounts. Chem. Res. 2000, 33, 27-36.

18. Antoine, O.; Bultel, Y.; Durand, R. Oxygen reduction reaction kinetics and mechanism on platinum nanoparticles inside Nafion (R). J. Electroanal. Chem. 2001, 499, 85-94.

19. Srivastava, C.; Balasubramanian, J.; Turner, C.H.; Turner, C.H.; Wiest, J.M. Formation mechanism and composition distribution of FePt nanoparticles. J. Appl. Phys. 2007, 102, 104310:1-104310:8. 
20. Chen, C.W.; Takezako, T.; Yamamoto, K.; Serizawa, T.; Akashi, M. PoIy(N-vinylisobutyramide)stabilized platinum nanoparticles: synthesis and temperature-responsive behavior in aqueous solution. Colloid Surface A 2000, 169, 107-116.

21. Collier, P.J.; Iggo, J.A.; Whyman, R. Preparation and characterisation of solvent-stabilised nanoparticulate platinum and palladium and their catalytic behaviour towards the enantioselective hydrogenation of ethyl pyruvate. J. Mol. Catal. A-Chem. 1999, 146, 149-157.

22. Guerin, S.; Attard, G.S. Electrochemical behaviour of electrodeposited nanostructured palladium plus platinum films in $2 \mathrm{M} \mathrm{H}_{2} \mathrm{SO}_{4}$. Electrochem. Commun. 2001, 3, 544-548.

23. Boccuzzi, F.; Chiorino, A.; Manzoli, M. Au/TiO ${ }_{2}$ nanostructured catalyst: effects of gold particle sizes on CO oxidation at 90 K. Mat. Sci. Eng. C-Bio. S. 2001, 15, 215-217.

24. Johnson, S.R.; Evans, S.D.; Mahon, S.W.; Ulman, A. Synthesis and characterisation of surfactantstabilised gold nanoparticles. Supramol. Sci. 1997, 4, 329-333.

25. Jin, B.K.; Ji, X.P.; Nakamura, T. Voltammetric study of interaction of Co(phen) ${ }_{3}{ }^{3+}$ with DNA at gold nanoparticle self-assembly electrode. Electrochim. Acta 2004, 50, 1049-1055.

26. Fu, Y.Z.; Yuan, R.; Xu, L.; Chai, Y.Q.; Zhong, X.; Tang, D.P. Indicator free DNA hybridization detection via EIS based on self-assembled gold nanoparticles and bilayer two-dimensional 3mercaptopropyltrimethoxysilane onto a gold substrate. Biochem. Eng. J. 2005, 23, 37-44.

27. Kang, J.W.; Li, X.N.; Wu, G.F.; Wang, Z.H.; Lu, X.Q. A new scheme of hybridization based on the Au-nano-DNA modified glassy carbon electrode. Anal. Biochem. 2007, 364, 165-170.

28. Kerman, K.; Morita, Y.; Takamura, Y.; Ozsoz, M.; Tamiya, E. Modification of Escherichia coli single-stranded DNA binding protein with gold nanoparticles for electrochemical detection of DNA hybridization. Anal. Chim. Acta 2004, 510, 169-174.

29. Kerman, K.; Saito, M.; Morita, Y.; Takamura, Y.; Ozsoz, M.; Tamiya, E. Electrochemical coding of single-nucleotide polymorphisms by monobase-modified gold nanoparticles. Anal. Chem. 2004, 76, 1877-1884.

30. Lu, W.S.; Lin, L.; Jiang, L. Nanogold hollow balls with dendritic surface for hybridization of DNA. Biosens. Bioelectron. 2007, 22, 1101-1105.

31. Maxwell, D.J.; Taylor, J.R.; Nie, S.M. Self-assembled nanoparticle probes for recognition and detection of biomolecules. J. Am. Chem. Soc. 2002, 124, 9606-9612.

32. Tsai, C.Y.; Chang, T.L.; Kuo, L.S.; Chen, P.H. Detection of electrical characteristics of DNA strands immobilized on self-assembled multilayer gold nanoparticles. Appl. Phys. Lett. 2006, 89, 203902:1-203902:3.

33. Wang, H.; Zhang, C.X.; Li, Y.; Qi, H.L. Electrogenerated chemiluminescence detection for deoxyribonucleic acid hybridization based on gold nanoparticles carrying multiple probes. Anal. Chim. Acta 2006, 575, 205-211.

34. Spadavecchia, J.; Prete, P.; Lovergine, N.; Tapfer, L.; Rella, R. Au nanoparticles prepared by physical method on Si and sapphire substrates for biosensor applications. J. Phys. Chem. B 2005, 109, 17347-17349.

35. Pan, J. Voltammetric detection of DNA hybridization using a non-competitive enzyme linked assay. Biochem. Eng. J. 2007, 35, 183-190. 
36. Yang, J.; Yang, T.; Feng, Y.Y.; Jiao, K. A DNA electrochemical sensor based on nanogoldmodified poly-2,6-pyridinedicarboxylic acid film and detection of PAT gene fragment. Anal. Biochem. 2007, 365, 24-30.

37. Kim, D.K.; Kerman, K.; Saito, M.; Sathuluri, R.R.; Endo, T.; Yamamura, S.; Kwon, Y.-S.; Tamiya, E. Label-free DNA biosensor based on localized surface plasmon resonance coupled with interferometry. Anal. Chem. 2007, 79, 1855-1864.

38. Zhu, N.N.; Chang, Z.; He, P.G.; Fang, Y.Z. Electrochemical DNA biosensors based on platinum nanoparticles combined carbon nanotubes. Anal. Chim. Acta. 2005, 545, 21-26.

39. Zhu, N.N.; Zhang, A.P.; Wang, Q.J.; He, P.G.; Fang, Y.Z. Electrochemical detection of DNA hybridization using methylene blue and electro-deposited zirconia thin films on gold electrodes. Anal. Chim. Acta 2004, 510, 163-168.

40. Yang, Y.H.; Wang, Z.J.; Yang, M.H.; Li, J.S.; Zheng, F.; Shen, G.L.; Yu, R.Q. Electrical detection of deoxyribonucleic acid hybridization based on carbon-nanotubes/nano zirconium dioxide/chitosan-modified electrodes. Anal. Chim. Acta 2007, 584, 268-274.

41. Shrestha, S.; Yeung, C.M.Y.; Mills, C.E.; Lewington, J.; Tsang, S.C. Chemically immobilized single-stranded oligonucleotides on praseodymium oxide nanoparticles as an unlabeled DNA sensor probe using impedance. Angew. Chem. Int. Ed. 2007, 46, 3855-3859.

42. Zhang, D.; Chen, Y.; Chen, H.Y.; Xia, X.H. Silica-nanoparticle-based interface for the enhanced immobilization and sequence-specific detection of DNA. Anal. Bioanal. Chem. 2004, 379, 1025-1030.

43. Wei, H.; Wang, E. Electrochemiluminescence-based DNA detection using guanine oxidation at electrostatic self-assembly of $\mathrm{Ru}(\mathrm{bpy})_{3}{ }^{2+}$-doped silica nanoparticles on indium tin oxide electrode. Chem. Lett. 2007, 36, 210-211.

44. Iijima, S. Helical microtubules of graphitic carbon. Nature 1991, 354, 56-58.

45. Trojanowicz, M. Analytical applications of carbon nanotubes: a review. Trac-Trend Anal. Chem. 2006, 25, 480-489.

46. Tang, T.; Peng, T.Z.; Shi, Q.C. Sequence determination of DNA pieces using carbon nanotube modified gold electrodes. Acta Chim. Sinica 2005, 63, 2042-2046.

47. Abdullin, T.I.; Nikitina, I.I.; Ishmukhametova, D.G.; Budnikov, G.K.; Konovalova, O.A.; Salakhov, M.K. Carbon nanotube-modified electrodes for electrochemical DNA-sensors. J. Anal. Chem. 2007, 62, 599-603.

48. Kerman, K.; Morita, Y.; Takamura, Y.; Tamiya, E. Escherichia coli single-strand binding proteinDNA interactions on carbon nanotube-modified electrodes from a label-free electrochemical hybridization sensor. Anal. Bioanal. Chem. 2005, 381, 1114-1121.

49. Erdem, A.; Papakonstantinou, P.; Murphy, H. Direct DNA hybridization at disposable graphite electrodes modified with carbon nanotubes. Anal. Chem. 2006, 78, 6656-6659.

50. Liang, Z.Q.; Lao, R.J.; Wang, J.W.; Liu, Y.B.; Wang, L.H.; Huang, Q.; Song, S.P.; Li, G.X.; Fan, C.H. Solubilization of single-walled carbon nanotubes with single-stranded DNA generated from asymmetric PCR. Int. J. Mol. Sci. 2007, 8, 705-713.

51. Xu, Y.; Jiang, Y.; Cai, H.; He, P.G.; Fang, Y.Z. Electrochemical impedance detection of DNA hybridization based on the formation of M-DNA on polypyrrole/carbon nanotube modified electrode. Anal. Chim. Acta 2004, 516, 19-27. 
52. Xu, Y.; Ye, X.Y.; Yang, L.; He, P.A.; Fang, Y.Z. Impedance DNA biosensor using electropolymerized polypyrrole/multiwalled carbon nanotubes modified electrode. Electroanalysis 2006, 18, 1471-1478.

53. Cai, H.; Xu, Y.; He, P.G.; Fang, Y.Z. Indicator free DNA hybridization detection by impedance measurement based on the DNA-doped conducting polymer film formed on the carbon nanotube modified electrode. Electroanalysis 2003, 15, 1864-1870.

54. Qi, H.; Li, X.X.; Chen, P.; Zhang, C.X. Electrochemical detection of DNA hybridization based on polypyrrole/ss-DNA/multi-wall carbon nanotubes paste electrode. Talanta 2007, 72, 1030-1035.

55. Li, J.; Liu, Q.; Liu, Y.J.; Liu, S.C.; Yao, S.Z. DNA biosensor based on chitosan film doped with carbon nanotubes. Anal. Biochem. 2005, 346, 107-114.

56. Bollo, S.; Ferreyra, N.F.; Rivas, G.A. Electrooxidation of DNA at glassy carbon electrodes modified with multiwall carbon nanotubes dispersed in chitosan. Electroanal. 2007, 19, 833-840.

57. Guo, M.L.; Chen, J.H.; Liu, D.Y.; Nie, L.H.; Yao, S.Z. Electrochemical characteristics of the immobilization of calf thymus DNA molecules on multi-walled carbon nanotubes. Bioelectrochemistry 2004, 62, 29-35.

58. Jung, D.H.; Kim, B.H.; Ko, Y.K.; Jung, M.S.; Jung, S.; Lee, S.Y.; Jung, H.-T. Covalent attachment and hybridization of DNA oligonucleotides on patterned single-walled carbon nanotube films. Langmuir 2004, 20, 8886-8891.

59. Guo, M.L.; Chen, J.H.; Nie, L.H.; Yao, S.Z. Electrostatic assembly of calf thymus DNA on multiwalled carbon nanotube modified gold electrode and its interaction with chlorpromazine hydrochloride. Electrochim. Acta 2004, 49, 2637-2643.

60. Chang, Z.; Zhu, N.N.; Zhao, K.; Fan, H.; He, P.-G.; Fang, Y.-Z. Study of polyaniline nanowire modified electrode for electrochemical DNA biosensor. Acta Chim. Sinica 2007, 65, 135-139.

61. Zhu, N.N.; Chang, Z.; He, P.G.; Fang, Y.Z. Electrochemically fabricated polyaniline nanowiremodified electrode for voltammetric detection of DNA hybridization. Electrochim. Acta 2006, 51, 3758-3762.

62. Nebel, C.E.; Yang, N.; Uetsuka, H.; Osawa, H.; Tokuda, N.; Williams, O. Diamond nano-wires, a new approach towards next generation electrochemical gene sensor platforms. Diam. Rel. Mat. 2008, 18, 910-917.

63. Zhu, N.N.; Zhang, A.P.; He, P.G.; Fang, Y.Z. Cadmium sulfide nanocluster-based electrochemical stripping detection of DNA hybridization. Analyst 2003, 128, 260-264.

64. Wang, J.B.; Profitt, J.A.; Pugia, M.J.; Suni, I.I. Au nanoparticle conjugation for impedance and capacitance signal amplification in biosensors. Anal. Chem. 2006, 78, 1769-1773.

65. Baca, A.J.; Zhou, F.M.; Wang, J.; Hu, J.B.; Li, J.H.; Wang, J.X.; Chikneyan, Z.S. Attachment of ferrocene-capped gold nanoparticle-streptavidin conjugates onto electrode surfaces covered with biotinylated biomolecules for enhanced voltammetric analysis. Electroanalysis 2004, 16, 73-80.

66. Li, J.H.; Hu, J.B.; Ding, X.Q.; Li, Q.L. DNA electrochemical biosensor based on functional gold nanoparticles-amplification. Chem. J. Chinese Univ. 2005, 26, 1432-1436.

67. Wang, J.; Li, J.H.; Baca, A.J.; Hu, J.B.; Zhou, F.M.; Yan, W.; Pang, D.-W. Amplified voltammetric detection of DNA hybridization via oxidation of ferrocene caps on gold nanoparticle/streptavidin conjugates. Anal. Chem. 2003, 75, 3941-3945. 
68. Li, J.H.; Hu, J.B. Functional gold nanoparticle-enhanced electrochemical determination of DNA hybridization and sequence-speciric analysis. Acta Chim. Sinica 2004, 62, 2081-2088.

69. Yao, X.; Li, X.; Toledo, F.; Zurita-Lopez, C.; Gutova, M.; Momand, J.; Zhou, F.M. Sub-attomole oligonucleotide and p53 cDNA determinations via a high-resolution surface plasmon resonance combined with oligonucleotide-capped gold nanoparticle signal amplification. Anal. Biochem. 2006, 354, 220-228.

70. Kalogianni, D.P.; Koraki, T.; Christopoulos, T.K.; Ioannou, P.C. Nanoparticle-based DNA biosensor for visual detection of genetically modified organisms. Biosens. Bioelectron. 2006, 21, 1069-1076.

71. Martins, R.; Baptista, P.; Raniero, L.; Doria, G.; Silva, L.; Franco, R.; Fortunato, E. Amorphous/nanocrystalline silicon biosensor for the specific identification of unamplified nucleic acid sequences using gold nanoparticle probes. Appl. Phys. Lett. 2007, 90, 023903:1-023903:3.

72. Liu, T.; Tang, J.; Jiang, L. The enhancement effect of gold nanoparticles as a surface modifier on DNA sensor sensitivity. Biochem. Bioph. Res. Co. 2004, 313, 3-7.

73. Nicu, L.; Guirardel, M.; Chambosse, F.; Rougerie, P.; Hinh, S.; Trevisiol, E.; Francois, J.-M.; Majoral, J.-P.; Caminade, A.-M.; Eric Cattan, E.; Bergaud, C. Resonating piezoelectric membranes for microelectromechanically based bioassay: detection of streptavidin-gold nanoparticles interaction with biotinylated DNA. Sensors Actuat. B-Chem. 2005, 110, 125-136.

74. Pang, L.L.; Li, J.S.; Jiang, J.H.; Shen, G.L.; Yu, R.Q. DNA-point mutation detection based on DNA ligase reaction and nano-Au amplification: a piezoelectric approach. Anal. Biochem. 2006, 358, 99-103.

75. Willner, I.; Patolsky, F.; Weizmann, Y.; Willner, B. Amplified detection of single-base mismatches in DNA using micro gravimetric quartz-crystal-microbalance transduction. Talanta 2002, 56, 847-856.

76. Cai, H.; Xu, Y.; Zhu, N.N.; He, P.G.; Fang, Y.Z. An electrochemical DNA hybridization detection assay based on a silver nanoparticle label. Analyst 2002, 127, 803-808.

77. Fu, Y.Z.; Yuan, R.; Xu, L.; Chai, Y.Q.; Liu, Y.; Tang, D.P.; Zhang, Y. Electrochemical impedance behavior of DNA biosensor based on colloidal Ag and bilayer two-dimensional sol-gel as matrices. J. Biochem. Bioph. Meth. 2005, 62, 163-174.

78. K'Owino, I.O.; Mwilu, S.K.; Sadik, O.A. Metal-enhanced biosensor for genetic mismatch detection. Anal. Biochem. 2007, 369, 8-17.

79. Xu, Y.; Cai, H.; He, P.G.; Fang, Y.Z. Probing DNA hybridization by impedance measurement based on CdS-oligonucleotide nanoconjugates. Electroanal. 2004, 16, 150-155.

80. Peng, H.; Soeller, C.; Cannell, M.B.; Bowmaker, G.A.; Cooney, R.P.; Travas-Sejdic, J. Electrochemical detection of DNA hybridization amplified by nanoparticles. Biosens. Bioelectron. 2006, 21, 1727-1736.

81. Katz, E.; Willner, I. Biomolecule-functionalized carbon nanotubes: applications in nanobioelectronics. Chem. Phys. Chem. 2004, 5, 1085-1104.

82. Zhang, R.Y.; Wang, X.M.; Chen, C. Electrochemical biosensing platform using carbon nanotube activated glassy carbon electrode. Electroanalysis 2007, 19, 1623-1627. 
83. Hwang, E.S.; Cao, C.F.; Hong, S.H.; Jung, H.-J.; Cha, C.-Y.; Choi, J.-B.; Kim, Y.-J.; Baik, S. The DNA hybridization assay using single-walled carbon nanotubes as ultrasensitive, long-term optical labels. Nanotechnology 2006, 17, 3442-3445.

84. Cao, C.F.; Kim, J.H.; Yoon, D.; Hwang, E.-S.; Kim, Y.-J.; Baik, S. Optical detection of DNA hybridization using absorption spectra of single-walled carbon nanotubes. Mater. Chem. Phys. 2008, 112, 738-741.

85. Wang, J.; Liu, G.D.; Jan, M.R. Ultrasensitive electrical biosensing of proteins and D.NA: Carbonnanotube derived amplification of the recognition and transduction events. J. Am. Chem. Soc. 2004, 126, 3010-3011.

86. Li, Y.; Qi, H.L.; Fang, F.; Zhang, C.X. Ultrasensitive electrogenerated chemiluminescence detection of DNA hybridization using carbon-nanotubes loaded with tris(2,2'-bipyridyl) ruthenium derivative tags. Talanta 2007, 72, 1704-1709.

87. Gao, Z.Q.; Agarwal, A.; Trigg, A.D.; Singh, N.; Fang, C.; Tung, C.-H.; Fan, Y.; Buddharaju, K.D.; Kong, J.M. Silicon nanowire arrays for label-free detection of DNA. Anal. Chem. 2007, 79, 3291-3297.

88. Hu, W.P.; Chen, S.J.; Huang, K.T.; Hsu, J.H.; Chen, W.Y.; Chang, G.L.; Lai, K.A. A novel ultrahigh-resolution surface plasmon resonance biosensor with an $\mathrm{Au}$ nanocluster-embedded dielectric film. Biosens. Bioelectron. 2004, 19, 1465-1471.

89. Ghanbari, K.; Bathaie, S.Z.; Mousavi, M.F. Electrochemically fabricated polypyrrole nanofibermodified electrode as a new electrochemical DNA biosensor. Biosens. Bioelectron. 2008, 23, $1825-1831$.

90. Kerman, K.; Morita, Y.; Takamura, Y.; Ozsoz, M.; Tamiya, E. DNA-directed attachment of carbon nanotubes for enhanced label-free electrochemical detection of DNA hybridization. Electroanalysis 2004, 16, 1667-1672.

91. Wang, J.; Liu, G.D.; Jan, M.R.; Zhu, Q.Y. Electrochemical detection of DNA hybridization based on carbon-nanotubes loaded with CdS tags. Electrochem. Commun. 2003, 5, 1000-1004.

92. Xia, Q.; Chen, X.; Zhao, K.; Liu, J.H. Synthesis and characterizations of polycrystalline walnutlike CdS nanoparticle by solvothermal method with PVP as stabilizer. Mater. Chem. Phys. 2008, 111, 98-105.

93. Zhang, W.; Yang, T.; Zhuang, X.; Guo, Z.; Jiao, K. An ionic liquid supported $\mathrm{CeO}_{2}$ nanoshuttlescarbon nanotubes composite as a platform for impedance DNA hybridization sensing. Biosens. Bioelectron. 2009, 24, 2417-2422.

94. Cai, H.; Wang, Y.Q.; He, P.G.; Fang, Y.H. Electrochemical detection of DNA hybridization based on silver-enhanced gold nanoparticle label. Anal. Chim. Acta 2002, 469, 165-172.

95. Cai, H.; Zhu, N.N.; Jiang, Y.; He, P.G.; Fang, Y.Z. Cu@Au alloy nanoparticle as oligonucleotides labels for electrochemical stripping detection of DNA hybridization. Biosens. Bioelectron. 2003, $18,1311-1319$.

96. Fu, Y.Z.; Yuan, R.; Chai, Y.Q.; Zhou, L.; Zhang, Y. Coupling of a reagentless electrochemical DNA biosensor with conducting polymer film and nanocomposite as matrices for the detection of the HIV DNA sequences. Anal. Lett. 2006, 39, 467-482.

97. Kerman, K.; Kobayashi, M.; Tamiya, E. Recent trends in electrochemical DNA biosensor technology. Meas. Sci. Technol. 2004, 15, R1-R11. 
98. Ye, Y.K.; Zhao, J.H.; Yan, F.; Zhu, Y.L.; Ju, H.X. Electrochemical behavior and detection of hepatitis B virus DNA PCR production at gold electrode. Biosens. Bioelectron. 2003, 18, 1501-1508.

99. Mannelli, I.; Minunni, M.; Tombelli, S.; Mascini, M. Quartz crystal microbalance (QCM) affinity biosensor for genetically modified organisms (GMOs) detection. Biosens. Bioelectron. 2003, 18, $129-140$.

(C) 2009 by the authors; licensee Molecular Diversity Preservation International, Basel, Switzerland. This article is an open-access article distributed under the terms and conditions of the Creative Commons Attribution license (http://creativecommons.org/licenses/by/3.0/). 